\title{
Design and performance analysis of stand-alone PV system at Al-Nahrain University, Baghdad, Iraq
}

\author{
Anas Lateef Mahmood, Amina Mahmoud Shakir, Bahaa Abdulkhaliq Numan \\ Electronic and Communications Engineering Departement, College of Engineering, Al-Nahrain University, Iraq
}

\begin{tabular}{l}
\hline Article Info \\
\hline Article history: \\
Received Oct 9, 2019 \\
Revised Dec 8, 2019 \\
Accepted Feb 7, 2020 \\
\hline
\end{tabular}

Keywords:

Partial shading

PV systems

Pvsyst6

Solar cells

Stand-alone

\begin{abstract}
The use of the stand-alone PV systems for electric power generation is important to meet the needs of electric power, especially in countries that have major problems in the generation and continuity of electricity such as Iraq. The aim of this research is to design and simulate a stand-alone PV system installed on the roof of the parking garage in the College of Engineering at Al-Nahrain University for the purpose of using the electrical energy generated by this system to meet the energy demand of the daily light for the parking garage and engineering laboratories buildings beside it. The main factor in the design was the total area of the roof of the parking garage. The Pvsyst6 program is used to simulate the suggested PV system and to determine the effect of partial shading which caused by the trees surrounding the garage on the available generated power of the system. A comparison was made between four types of solar panels to see the suitability of these types to the weather conditions in Iraq, in addition to the impact of the shadows surrounding the garage. These types of solar panels were (CIS SL2-145, CdTe F-4112-3, Poly JAP6-60-260, and Mono JAM660-260), CdTe type showed better performance compared to other types in terms of available energy generated because it has small losses due to temperature and shadows. It was found that the best tilt angle of the solar panels in the case of shadows is 19 o to the south. Finally, the financial analysis was made to see the economic feasibility of this PV system and it is found that the PV system that uses CdTe panels has the smallest $\mathrm{kWh}$ unit price $(0.236 \$ / \mathrm{kWh})$ as compared with the other three types.
\end{abstract}

This is an open access article under the CC BY-SA license.

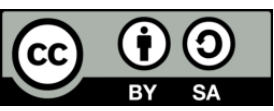

\section{Corresponding Author:}

Anas Lateef Mahmood,

Electronic and Communications Departement, College of Engineering

Al-Nahrain University, Jadriyah, Baghdad, Iraq.

Email: anas.lateef@eng.nahrainuniv.edu.iq

\section{INTRODUCTION}

The issue of clean electricity generation using solar cell systems is one of the most important things right now, especially in countries which have problems in electricity generation from fossil-fuelled power stations. The problems are apprehended about the way of energy harnessing and utilization. In this point, fast pace revolutionary techniques are invented to solve these problems, renewable energy resources trans-form the passive energy to a clean active energy used to generate electricity with no emissions such as PV systems [1]. Over the past years, interest has been given to the issue of the electric power generation that rely on solar energy, many researches published by researchers and engineers in this important field. Solar energy systems are divided into two main types: the stand-alone and the grid connected pv systems. A standalone PV system use to feed the load directly and it is isolated from the main electrical grid, during daylight it generates electricity to supply the demand load and charge the batteries while at night and cloudy days it 
depends on the battery bank to supply the demand load. The PV panels and batteries generate DC power and the inverter converts it to AC power in order to supply the load.

In Iraq there is a problem in the provision of electric power throughout the country. This problem has been going on since the eighties of the last century not because of the lack of fuel because Iraq is a rich country in oil it is one of the oil-exporting countries and has the second reserve in the world. It also has reserves of natural gas in fourth place in the world [2]. The problem of luck of continuity in electric power in Iraq because of the destruction of a number of electric power stations as a result of successive wars in this country in addition to the age, poor maintenance and development of the remaining stations. Iraq's electrical infrastructure problems are not unique and other countries have faced similar problems and have found solar PV systems to be a viable solution $[2,3]$.

In this research, an electrical power generation system was designed and simulated using standalone PV system for the purpose of operating the internal lighting system of the laboratories buildings of the College of Engineering (Engineering Workshops) and the external lighting of the car parking garage belonging to the College of Engineering at Al-Nahrain University. The design depends on calculating the space area of the car parking garage roof and the possible number of the PV modules suitable for the installation in this garage. The main reason of this design is to provide continuous lighting for laboratories and car parking garage due to frequent interruptions in the electricity from the main grid as well as for the purpose of generating clean energy free of pollution. Figure 1 shows the block diagram of the stand-alone system.

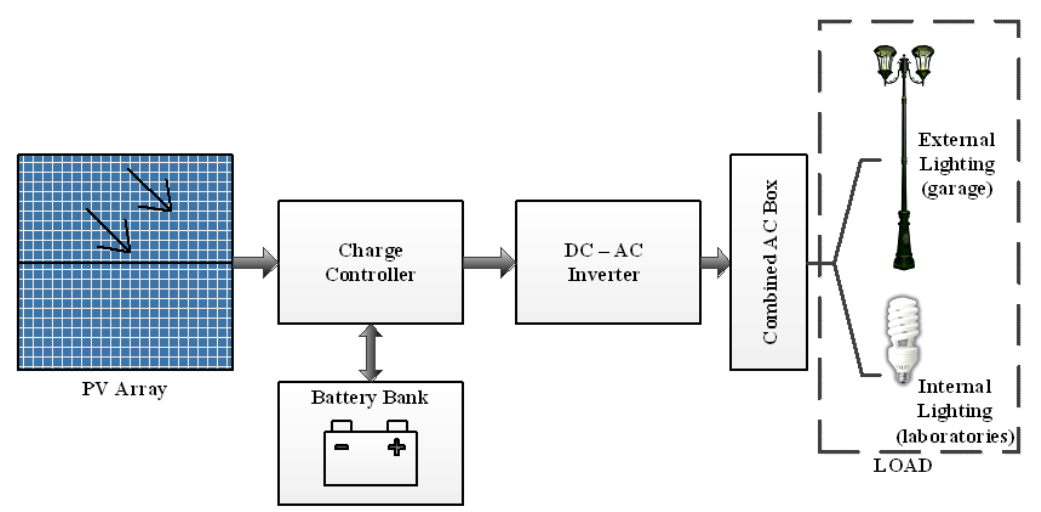

Figure 1. System block diagram.

The first step in designing a PV system is to choose the suitable location for solar panels and other components such as batteries, charge controller and inverter. Otherwise, the result from the system will not have desired power output [4]. As mentioned above the solar panels will be placed on the garage roof while the rest components (e.g. inverter, charge controller and the batteries) will be placed inside the workshop buildings near the garage. Figures 1 and 2 show the proposed location of the stand-alone PV system in the garage belongs to the College of Engineering of Al-Nahrain University in Baghdad.

There are four car sheds in the garage each shed accommodate different number of cars, the four sheds have different areas with dimensions of $(A=5 \mathrm{~m} \times 25 \mathrm{~m}, \mathrm{~B}=5 \mathrm{~m} \times 20 \mathrm{~m}, \mathrm{C}=5 \mathrm{~m} \times 17 \mathrm{~m}, \mathrm{D}=5 \mathrm{~m} \times 11.5 \mathrm{~m})$. It seems clear from the above figures that the garage is surrounded by a number of tall trees. These trees, in turn, will cause the problem of the presence of shadows on the solar panels, which will reduce the generated energy of these panels. Therefore it is very important to take into account the problem of shadows caused by these trees in the computer simulation of the proposed solar system. The Pvsyst6 software package will be used to predict the simulation results of the proposed stand-alone PV system with taking into account the problem of shadows falling on the solar panels.

The idea of exploiting car sheds in universities exists and is implemented in a number of international universities, for example in reference [4] a stand-alone photovoltaic (PV) system with solar PV peak power of $1285 \mathrm{~kW}$ is designed to meet the daily light energy demand of Flarsheim Hall at the University of Missouri-Kansas City. System Advisory Model (SAM) and PVwatts simulation tools were used to design and optimize the system, there is no shading analysis in this work. In [5] multiple locations were assessed Illinois State University to determine the feasibility of installing parking canopies coupled with solar photovoltaic (PV) systems and electric vehicle (EV) charging stations and to show these two systems' 
effectiveness if they are implemented together. In [6] A detailed work has been done for solar car parking site selection and maximum solar electric power generation and its capacity effects with the shading of nearby trees and buildings by using the HelioScope online software developed by Folsom Labs, it is found that the monopitch canopy is the best to mount at solar car parking lots. Other related works could be found in [7, 8].

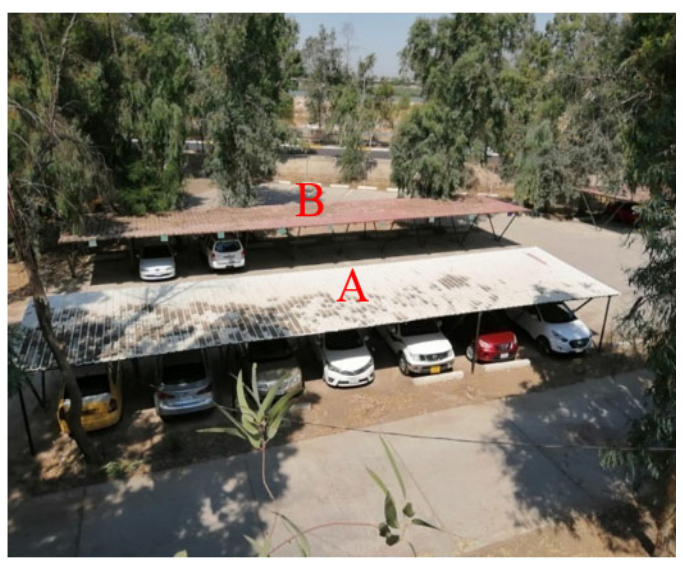

Figure 2. Cars garage sheds $\mathrm{A}$ and $\mathrm{B}$.

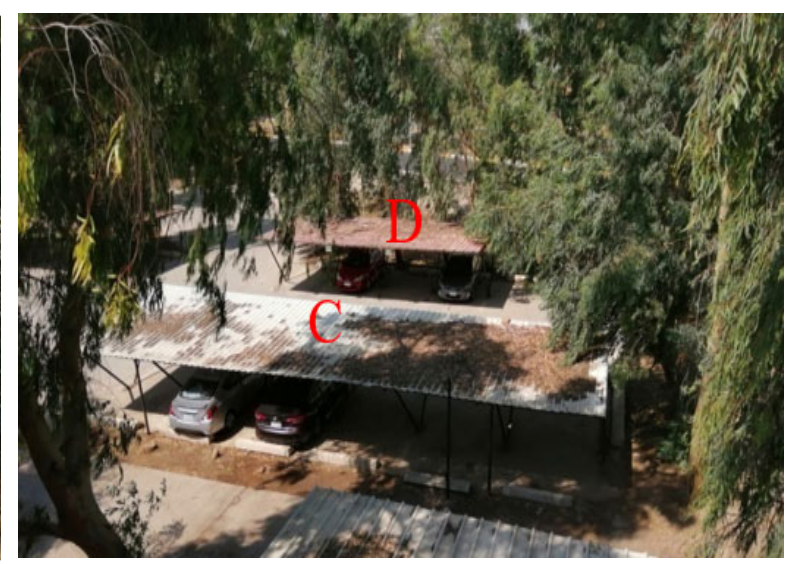

Figure 3. Cars garage sheds $\mathrm{C}$ and $\mathrm{D}$.

\section{SOLAR IRRADIATION IN BAGHDAD}

When starting the design process for the stand-alone PV system it is important to know the meteorological data of the area where the system will be installed. Table 1 below shows the meteorological data for Jadriyah region in Baghdad city where Al-Nahrain University located including global horizontal irradiance (GHI), wind speed and average air temperature. These data were obtained from a meteorological observatory belong to the Iraqi Ministry of Science and Technology located in the same area for the year 2017.

The latitude of Baghdad, Iraq is 33.312805, and the longitude is 44.361488. Other information about suggested place in Al-Nahrain University could be found in [9] includes monthly mean sun shine hours, yearly solar radiation with different tilt angles and hence the best direction of the tilt angle for the solar panels.

Table 1. Meteorological data of Jadriyah region.

\begin{tabular}{cccc}
\hline Month & GHI $\left(\mathrm{kWh} / \mathrm{m}^{2}\right)$ & Wind speed $(\mathrm{m} / \mathrm{s})$ & Average air temp. ${ }^{\circ} \mathrm{C}$ \\
\hline January & 78 & 2.45 & 10.4 \\
February & 107.6 & 2.55 & 11.4 \\
March & 136.9 & 2.63 & 18 \\
April & 162.4 & 2.94 & 23.6 \\
May & 200.6 & 2.97 & 31.2 \\
June & 229.7 & 3.58 & 35.5 \\
July & 222.8 & 3.63 & 39.8 \\
August & 199.1 & 3.46 & 39.5 \\
September & 141.8 & 2.74 & 35.8 \\
October & 103.6 & 2.38 & 27.3 \\
November & 73.09 & 2.33 & 19.7 \\
December & 76.9 & 2.53 & 14.6 \\
\hline
\end{tabular}

Because of the occurrence of Iraq in the northern hemisphere, the best orientation of solar panels is to the south in order to obtain the highest amount of solar radiation falling on the panels and thus obtain the best energy of the panels. The annually optimal tilt angel has been obtained for Baghdad city in $[10,11]$ and it is found that the the peak output power solar panel be in south facing orientation because the sun path be proportionally perpendicular to solar panel with maximum annually solar radiation at tilt between $30^{\circ}$ and $35^{\circ}$. A two axis solar radiation tracker was proposed by the author for Baghdad city in [12]. 


\section{SYSTEM DESIGN}

The designed solar power system consists of four main parts: solar panels, batteries, charge controller and inverter. Four types of solar panels were tested for the purpose of comparison between them and see which of these panels will give greater energy in the weather conditions of Iraq, which is characterized by high temperature in summer. Also to see the effect of the shadows fallen on these panels as a result of the presence of many trees surrounding the garage. The main factor in the selection of solar panel types is the convergence in the efficiency values of these panels. Table 2 shows the characteristics of the PV modules [13-16].

Table 2. PV modules characteristics.

\begin{tabular}{ccccccc}
\hline PV model & $\begin{array}{c}\text { Maximum } \\
\text { power } P_{\max }(\mathrm{W})\end{array}$ & $\begin{array}{c}\text { Maximum } \\
\text { power voltage } \\
V_{m p}(\mathrm{~V})\end{array}$ & $\begin{array}{c}\text { Maximum } \\
\text { power current } \\
I_{m p}(\mathrm{~A})\end{array}$ & $\begin{array}{c}\text { Short circuit } \\
\text { current } I_{S C}(\mathrm{~A})\end{array}$ & $\begin{array}{c}\text { Open circuit } \\
\text { voltage } V_{O C}(\mathrm{~V})\end{array}$ & $\begin{array}{c}\text { Efficiency } \eta \\
\text { JAM6-60-260 }\end{array}$ \\
JAP6-60-260 & 260 & 30.81 & 8.44 & 8.92 & 38.08 & 15.9 \\
FS-4112-3 & 112.5 & 30.63 & 8.49 & 9.04 & 37.98 & 15.9 \\
SL2-145 & 145 & 68.5 & 1.64 & 1.83 & 1.81 & 107.8 \\
\hline
\end{tabular}

\subsection{Inter row spacing}

The effect of inter row spacing for tilted or ground mounted PV systems is essential as there is a possibility of inter-row shading. Inter-row shading occurs when the solar PV module in front casts a shadow on the module behind it and hence there is a reduction of PV yield. The main parameters that must be known to calculate the minimum spacing between the rows in order to minimize the inter row shading are [17]:

- Module length and width.

- Required array length, width and area.

- Module orientation.

- Tilt angle.

- Sun path chart.

For the two rows shown in figure 4 , the inter row spacing D can be found using the following equation [18]:

$$
\mathrm{D}=\frac{\mathrm{H}}{\tan \alpha} \cos \mathrm{Z}
$$

Where $\mathrm{D}$ is the row space, $\mathrm{H}$ is the module height, $\alpha$ is the altitude angle.

The module height is the vertical distance from the horizontal plane on which all the stands are to the top of the module. It may be calculated using Pythagoras theorem

$$
\mathrm{H}=\text { Module length }(\mathrm{L}) \times \sin \beta
$$

Where $\beta$ is the array tilt angle.

The altitude angle $\alpha$ can be found using the sun path chart for the specified location and at a certain time. Figure 5 shows the sun path chart for the geographical location (latitude $33.28^{\circ} \mathrm{N}$, longitude $44.37^{\circ} \mathrm{E}$ ) [19]. For minimum row spacing the altitude angle is taken for the worst condition (Sun window "sunny hours per day" from 9:00 AM to 15:00 PM on 21 December (winter solstice)).

For a module length $\mathrm{L}=1 \mathrm{~m}$ mounted on a tilt angle of $30^{\circ}$ facing the south $(\mathrm{z}=0)$ and the altitude angle is approximately taken as $18^{\circ}$ (figure 5) the minimum row spacing is equal to $1.562 \mathrm{~m}$ (in this paper it is taken as $2 \mathrm{~m}$ ). In order to minimize the effect of row shading the front row is taken to be half of the height of the back row.

The total area of the four shads equal to $367.5 \mathrm{~m}^{2}$ and it is found that by using $2 \mathrm{~m}$ row spacing and facing the panels to the south that this area can handle $(4 \times 32)$ panels from the monocrystalline JAM6-60-260, or $(4 \times 32)$ panels from the polycrystalline JAP6-60-260, or $(2 \times 145)$ panels from the CdTe FS-4112-3, or $(2 \times 111)$ panels from the CIS SL2-145.

Int J Pow Elec \& Dri Syst, Vol. 11, No. 2, June 2020 : 921 - 930 


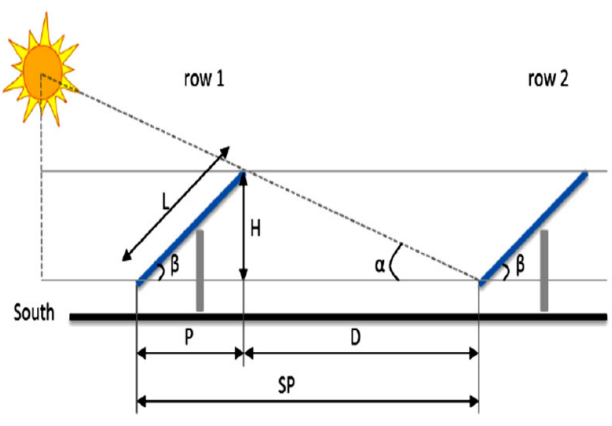

Figure 4. Side view of tilted PV-array.

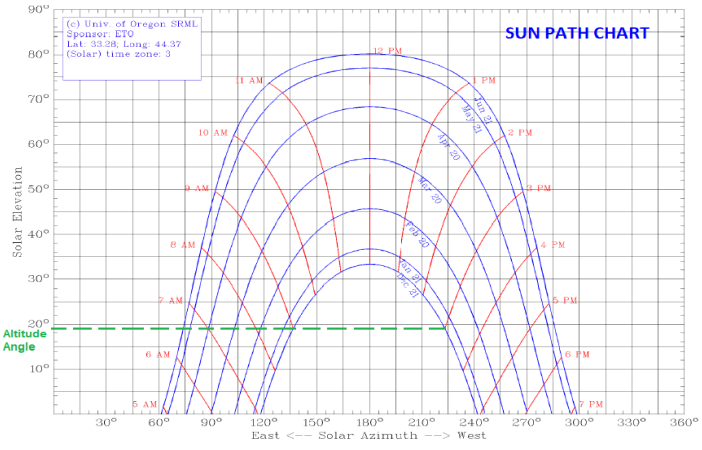

Figure 5. Sun Path for the geographical location.

\subsection{Design procedure}

The design procedure of the proposed system will be divided into two cases; Case 1. PV system analysis without the shading effect of trees, Case 2. PV system analysis with the shading effect of trees.

The modelling of the detailed shadow analysis, losses, and annual generation was performed by Pvsyst6 software package. After a detailed shadow analysis, the optimization of the PV systems is performed at different tilt angles for the maximum utilization of photovoltaic energy and maximum efficiency. Each case will be described in details as shown below.

\section{Case 1. PV system analysis without the shading effect of trees.}

The Pvsyst6 program is used to calculate the total nominal solar power for the available area of the four shads (A, B, C, and D) for each type of the PV panels shown in table 2. All the panels were oriented to the south and the tilt angle of the PV panels was changed from $17^{\circ}$ to $38^{\circ}$ in order to find the best angle which gives maximum generated energy, and it is found that the best tilt angle for all types of PV panels was $30^{\circ}$ as shown in Figure 6.

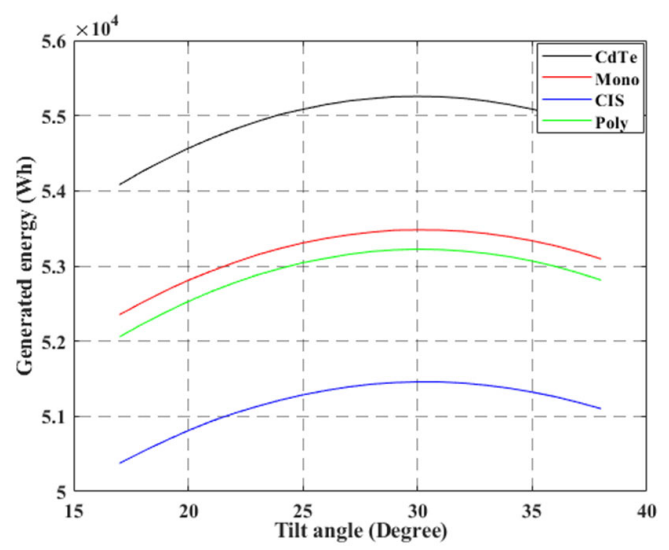

Figure 6. System generated energy without shading.

However, table 3 show the values of the annual available energy, performance ratio, irradiation loss and temperature loss for each type of the PV panels without shading effect. It is clear that from figure 6 and table 3 that the CdTe FS-4112-3 PV panels gave the highest annual available energy and this is because of the small values of irradiation and temperature loss of this type, also it have the highest performance ratio. In this simulation the nearby tree shading effect are ignored to know the maximum nominal solar energy generation and the temperature is considered the biggest factor in the photovoltaic module working performance.

Table 3. System annual generation and losses at tilt angle $30^{\circ}$ without shading. 


\begin{tabular}{ccccc}
\hline PV model & $\begin{array}{c}\text { Annual available } \\
\text { energy }(\mathrm{kWh} / \mathrm{yr})\end{array}$ & $\begin{array}{c}\text { Performance ratio } \\
\%\end{array}$ & Irradiation loss \% & $\begin{array}{c}\text { Temperature loss } \\
\%\end{array}$ \\
\hline JAM6-60-260 & 53480 & 74.6 & 0.29 & 11.06 \\
JAP6-60-260 & 51459 & 73.65 & 0.39 & 12.2 \\
FS-4112-3 & 55256 & 76.5 & 0.16 & 7.88 \\
SL2-145 & 53224 & 76.46 & 1.01 & 8.79 \\
\hline
\end{tabular}

\section{Case 2. PV system analysis with the shading effect of trees.}

The car garage is covered by nearby tall trees, so it is necessary to perform the shadow analysis of these trees to know the diffused solar radiation on PV modules and the effect on annual solar PV generation. Figure 7 shows the 3D plot of car garage using the Pvsyst6 program; it is assumed that the trees have $(15 \mathrm{~m}$ height, $5 \mathrm{~m}$ medium diameter, and $2.5 \mathrm{~m}$ trunk). The tilt angle of the $\mathrm{PV}$ panels was changed from $17^{\circ}$ to $38^{\circ}$ in order to find the best angle which gives maximum generated energy, and it is found that the best tilt angle for all types of PV panels was $19^{\circ}$ as shown in figure 8 .

Table 4 show the values of the annual available energy, performance ratio, irradiation loss and temperature loss for each type of the PV panels with shading effect. The CdTe FS-4112-3 PV panels still gave the highest annual available energy $(41363 \mathrm{kWh} / \mathrm{yr})$, therefore, the authors recommended to use this type of PV panels in the design of the proposed PV system due to its high available energy and performance ratio with small temperature and irradiation losses as compared with the other three types.

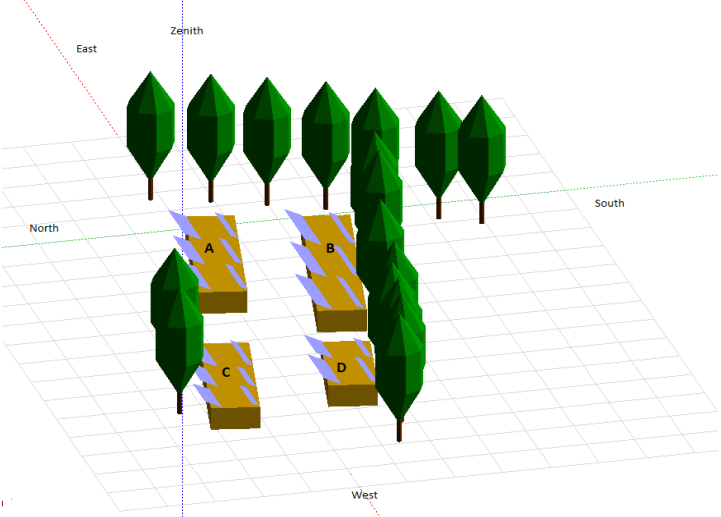

Figure 7. 3D plot of cars garage using Pvsyst6.

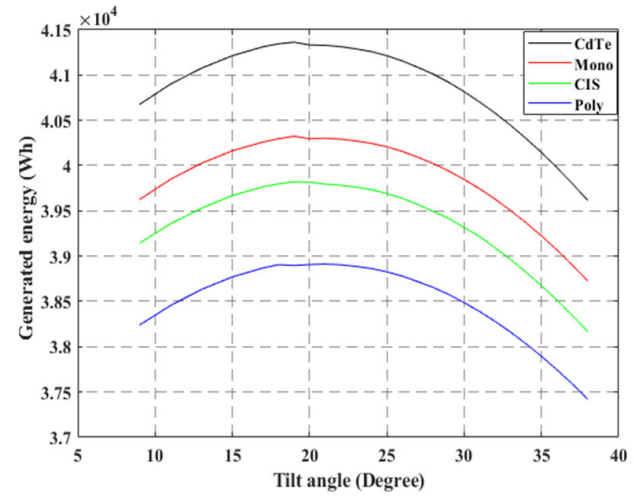

Figure 8. System generated energy with shading.

Table 4. System annual generation and losses at tilt angle $19^{\circ}$ with shading.

\begin{tabular}{ccccc}
\hline PV model & $\begin{array}{c}\text { Annual available } \\
\text { energy }(\mathrm{kWh} / \mathrm{yr})\end{array}$ & $\begin{array}{c}\text { Performance ratio } \\
\%\end{array}$ & Irradiation loss \% & $\begin{array}{c}\text { Temperature loss } \\
\%\end{array}$ \\
\hline JAM6-60-260 & 40324 & 59.9 & 0.75 & 9.43 \\
JAP6-60-260 & 38897 & 57.71 & 0.88 & 10.37 \\
FS-4112-3 & 41363 & 62.36 & 0.19 & 6.82 \\
SL2-145 & 39120 & 61.08 & 1.66 & 7.57 \\
\hline
\end{tabular}

The simulation of the PV system for each type of PV panel with shading effect shows that the number of batteries used (type Rolls S12-290 AGM) are equal to $(8 \times 12)$ for each case also the daily generated energy $\left(E_{L}\right)$ are equal to $146688 \mathrm{Wh}$ /day for the CdTe PV panel type while for the other three types it is equal to $146400 \mathrm{Wh} /$ day. Therefore, the following results will focus on the CdTe type with shading effect because of its high generated energy among the others. Figure 9 shows the effective energy at the output of the array against global incident irradiation while figure 10 shows the normalized energy for each month during the year. Table 5 shows the main results for the proposed system using CdTe PV panels. 


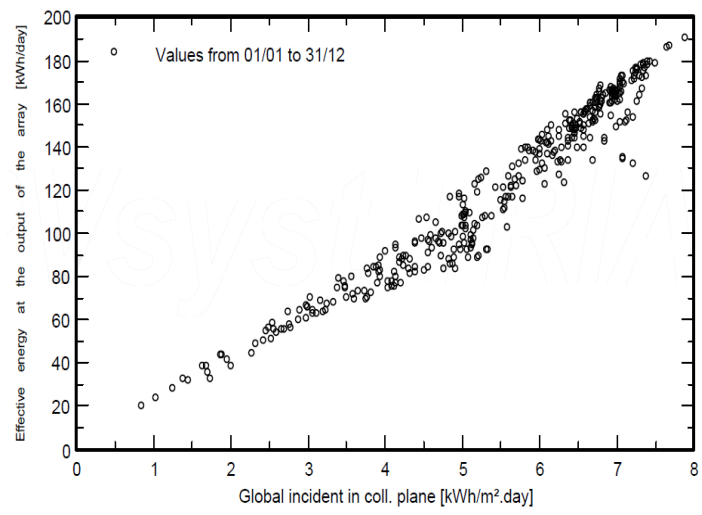

Figure 9. Effective energy of the array.
Normalized productions (per installed $\mathrm{kWp}$ ): Nominal power $32.6 \mathrm{kWp}$

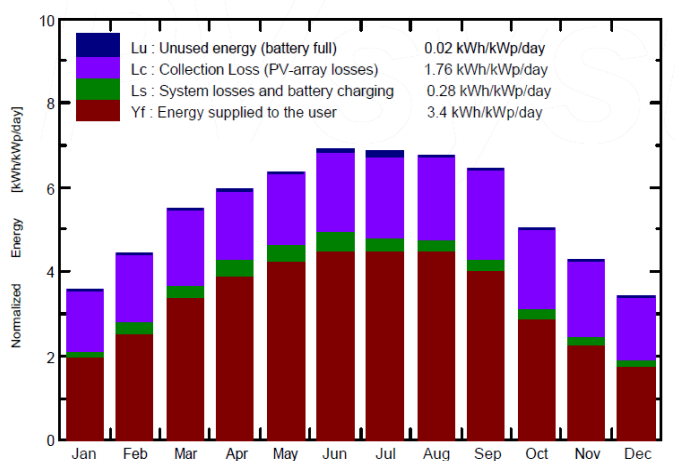

Figure 10. Normalized energy of the PV system.

Table 5. Simulation variant balances and main results.

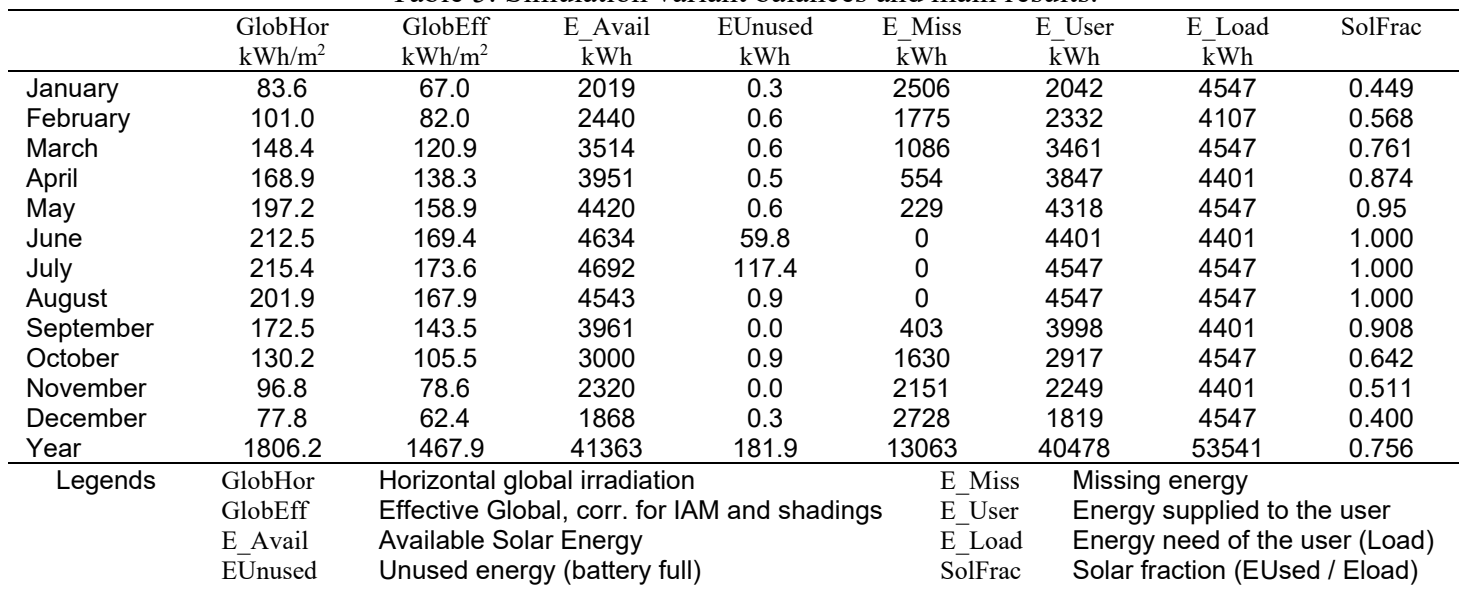

\section{FINANCIAL ANALYSIS}

The financial analysis must be carried out according to the longest life component of all system parts. For the PV modules used the life cycle is around 25 years, while for the storage batteries it is 10 years. Therefore the batteries need to be replaced twice during the 25 years. The PV module costs $\left(P V_{C}\right)$, storage batteries cost $\left(B_{C}\right)$, inverter cost $\left(I n v_{C}\right)$ and charge controller cost $\left(C_{C}\right)$ costs were taken from the FreeCleanSolar.com web site. The installation cost $\left(I_{C}\right)$ is taken as $10 \%$ of the PV panels cost. Given an inflation rate (i) of $4 \%$ and discount rate (d) of $8 \%$, the system life cycle cost and the unit electrical cost can be estimated as shown below [20].

The annual Operation and Maintenance cost $\left(O M_{C}\right)$ costs can be calculated as follows;

$$
O M_{C}=2 \% \mathrm{PV}_{\mathrm{C}} \times\left(\frac{1+\mathrm{i}}{1+\mathrm{d}}\right)\left[\frac{1-\left(\frac{1+\mathrm{i}}{1+\mathrm{d}}\right)^{25}}{1-\left(\frac{1+\mathrm{i}}{1+\mathrm{d}}\right)}\right]
$$

Since the life cycle of the used battery is equal to 10 years then it must be replaced two times during the 25 years. The first and second battery replacement costs $\left(B_{C 1}\right.$ and $\left.B_{C 2}\right)$ are calculated after 10 and 20 years respectively as follows;

$$
\begin{aligned}
& B_{C 1}=\mathrm{B}_{\mathrm{C}}\left[\frac{1-\mathrm{i}}{1-\mathrm{d}}\right]^{10} \\
& B_{C 1}=\mathrm{B}_{\mathrm{C}}\left[\frac{1-\mathrm{i}}{1-\mathrm{d}}\right]^{20}
\end{aligned}
$$

The system's life cycle cost $\left(L C_{C}\right)$ can be calculated as follows; 


$$
L C_{C}=P V_{C}+B_{C}+B_{C 1}+B_{C 2}+I n v_{c}+C_{C}+I_{C}+O M_{C}
$$

The annual life cycle cost $\left(A L C_{C}\right)$ can be calculated as follows;

$$
A L C_{C}=\mathrm{LC}_{\mathrm{C}}\left[\frac{1-\left(\frac{1+\mathrm{i}}{1+\mathrm{d}}\right)}{1-\left(\frac{1+\mathrm{i}}{1+\mathrm{d}}\right)^{25}}\right]
$$

The annual life cycle cost in addition to the daily generated energy $\left(E_{L}\right)$ by the PV system can be used to find the unit electrical cost $\left(U_{C}\right)$ in $\$ / \mathrm{kWh}$ as follows [21];

$$
U_{C}=\frac{A L C_{C}}{365 \times E_{L}}
$$

According to the above methodology, table 6 summarizes the cost analysis of the PV system for each type of the four PV panels. The costs of cables, design, metering and control devices are lamped together as $10 \%$ of equipment cost.

Table 6. Cost analysis of the PV system.

\begin{tabular}{ccccccc}
\hline PV model & $\begin{array}{c}\text { PV module unit } \\
\text { cost/total cost }\end{array}$ & $\begin{array}{c}\text { Battery unit } \\
\text { cost/total cost }\end{array}$ & $\begin{array}{c}\text { Inverter unit } \\
\text { cost } / \text { total cost }\end{array}$ & $\begin{array}{c}\text { Controller unit } \\
\text { cost } / \text { total cost }\end{array}$ & $\begin{array}{c}\text { Daily generated } \\
\text { energy }\left(E_{L}\right)\end{array}$ & $\begin{array}{c}\text { Unit electrical } \\
\text { cost }\left(U_{C}\right)\end{array}$ \\
\hline JAM6-60-260 & $\$ 390 / \$ 49920$ & $\$ 590 / \$ 66080$ & $\$ 1000 / \$ 2000$ & $\$ 1000 / \$ 2000$ & $146400 \mathrm{Wh} /$ day & $0247 \$ / \mathrm{kWh}$ \\
JAP6-60-260 & $\$ 390 / \$ 49920$ & $\$ 590 / \$ 66080$ & $\$ 1000 / \$ 2000$ & $\$ 1000 / \$ 2000$ & $146400 \mathrm{Wh} /$ day & $0247 \$ / \mathrm{kWh}$ \\
FS-4112-3 & $\$ 150 / \$ 43500$ & $\$ 590 / \$ 66080$ & $\$ 1000 / \$ 2000$ & $\$ 1000 / \$ 2000$ & $146688 \mathrm{Wh} /$ day & $0236 \$ / \mathrm{kWh}$ \\
SL2-145 & $\$ 260 / \$ 57720$ & $\$ 590 / \$ 66080$ & $\$ 1000 / \$ 2000$ & $\$ 1000 / \$ 2000$ & $146400 \mathrm{Wh} /$ day & $0259 \$ / \mathrm{kWh}$ \\
\hline
\end{tabular}

\section{CONCLUSION}

In this research, the car sheds in the garage of the College of Engineering were utilized for the purpose of designing a stand-alone PV system. The electrical energy generated from this PV system was suggested for use in providing electrical energy for the external lighting of the garage and the internal lighting of the workshops located in the building adjacent to the garage. Four types of solar cells with comparable efficiency were used and compared to see which of these types is suitable for use in Iraq's high temperature summer climate. The results show that CdTe solar panel is better than the other three types because it has few losses due to temperature rise. The economic analysis of the system showed that this type provides the lowest price per kilowatt hour unit when compared with other previous works $(0.238 \$ / \mathrm{kWh}$ in Iraq) such as in [22]. The presence of high trees surrounding the garage and the resulting shadows from it had a noticeable effect in reducing the electrical energy generated by the system. The presence of shadows has an effect on the optimal tilt angle of solar panels; for example, it is found by simulation that the best tilt angle is 19 degrees instead of 30 degrees in the proposed system. It is possible to reduce the impact of shadows caused by trees surrounding the site by conducting a pruning process of these trees, for example, it is possible to increase the annual energy from the panels by $7.6 \%$ if the trees have $(12 \mathrm{~m}$ height, $3.5 \mathrm{~m}$ medium diameter). One of the main problems that may face the work of the proposed system is the problem of the accumulation of dust and leaves falling on the solar panels, which will lead to reduce the generated energy of the panel, especially since the atmosphere of Iraq is characterized by the presence of dust in summer. Therefore, regular cleaning of the solar panels should be carried out for the purpose of removing the impact of dust and dirt accumulated on them. As a future work to this paper it is possible to reduce the shading effect by using PV array configuration, some of these configurations could be found in [23-25].

\section{REFERENCES}

[1] Zaid Hussein Ali, Abdullah Khalid Ahmed, Amer Tayes Saeed, "Modeling solar modules performance under temperature and solar radiation of western Iraq" International Journal of Power Electronics and Drive System (IJPEDS), Vol. 9, No. 4, pp. 1842-1850, Dec 2018.

[2] Curtis Austin, Ralph Borja, and Jeffery Phillips, "A study examining photovoltaic solar power as an alternative for the rebuilding of the Iraqi electrical power generation infrastructure," mba professional report, naval postgraduate school (nps): Monterey, California, 2005.

[3] Fayadh M. Abed, Y. Al-Douri, Ghazy M. Y. Al-Shahery, "Review on the energy and renewable energy status in Iraq: The outlooks," Renewable \& Sustainable Energy Reviews, vol. 39, pp. 816-827, Nov 2014.

Int J Pow Elec \& Dri Syst, Vol. 11, No. 2, June 2020 : 921 - 930 
[4] Ahmed Alahmed, Salahudin Iqbal Sidiki, Yahya Alharthi, Ghulam M. Chaudhry, Mahbube K. Siddiki, "Design, simulation and financial analysis of Stand-alone Photovoltaic System at University of Missouri-Kansas City, Missouri, USA," IEEE 43 ${ }^{\text {rd }}$ Photovoltaic Specialists Conference (PVSC), pp. 3287-3291, 2016.

[5] Austin Bushur, Kevin Ward, Tommy Flahaven, Tom Kelly, Jin H. Jo, and Matt Aldeman, "Techno-economic evaluation of installing EV and PV combined infrastructure on Academic Institution's Parking Garages in Illinois," AIMS Energy, USA, vol. 7, no. 1, 2019, pp. 31-45.

[6] Farhana Umer, et al, "Design and optimization of solar carport canopies for maximum power generation and efficiency at Bahawalpur," Hindawi International Journal of Photoenergy, vol. 2019, pp. 1-8, 2019.

[7] Peter Gevorkian, "Solar Power in building design the engineer's complete design resource," McGraw-Hill, 2008, DOI: $10.1036 / 0071485635$.

[8] C. Jackson, G Hartnell "Solar car parks: a guide for owners and developers," BRE National Centre, 2016.

[9] A. L. Mahmood, "Design and simulation of stand-alone pv system for electronic and communications engineering department laboratories in Al-Nahrain University," EAI Endoresd Transactions on Energy Web. Vol. 6, Issue 21, 2019, Doi: 10.4108/eai.13-7-2018.156438.

[10] Afaneen A. Abbood, Mohammed A. Salih, Hasan N. Muslim, "Management of electricity peak load for residential sector in Baghdad city by using solar generation," International Journal of Energy and Environment, vol. 8, no. 1, pp. 63-72, 2017.

[11] Emad Jaleel Mahdi, Sahib Nama Abdul-Wahid, Sarmad Shaker Abdulstar, Sabiha A. Sahab, Asmaa Hassan Mosli, "Optimum Orientation of Solar Panels in Baghdad city," Journal of Basrah Researches ((Sciences)), vol. 37, no. 3, June 2011.

[12] Anas Lateef Mahmood, "Date/Time Operated Two Axis Solar Radiation Tracking System for Baghdad City" International Journal of Applied Engineering Research, vol. 13, no. 7, pp. 5534-5537, 2018.

[13] http://www.solardesigntool.com/components/module-panel-solar/JA-Solar/1655/JAM6-60-260-SI/specificationdata-sheet.html

[14] https://www.solarsupply.se/cms/wp-content/uploads/2012/02/JAP6-60-240-260-3BB.pdf

[15] http://www.solardesigntool.com/components/module-panel-solar/First-Solar/3895/FS-4112-3/specification-datasheet.html

[16] https://solibrosolar.com/fileadmin/image/05_News_Downloads/Downloads/Data_sheets/G2.2/Solibro_datasheet_SL2_G22_2017-04_Rev03_EN.pdf

[17] Soteris A. Kalogirou, “Solar Energy Engineering," 2nd ed. (Academic Press), 2014.

[18] Olatunde Isiolaotan, Hartmut Androsch, Dr. Helmut Stadter, "Solar Photovoltaic Installation Supervision," 3rd ed. (GIZ, NESP), 2016.

[19] http://solardat.uoregon.edu/PolarSunChartProgram.php

[20] E. T. El Shenawy, et al, "Design and Optimization of Stand-alone PV System for Egyptian Rural Communities," International Journal of Applied Engineering Research, vol. 12, no. 20, pp. 10433-10446, 2017.

[21] Elieser Tarigan, Djuwari, Lasman Purba, "Assessment of PV Power Generation for Household in Surabaya Using Solar GIS-pv Planner Simulation,” Energy Procedia, vol. 47, pp. 85-93, 2014.

[22] A. Al-Karaghouli and L. Kazmerski, "Optimization and life-cycle cost of health clinic PV system for a rural area in southern Iraq using HOMER software," Solar Energy, vol. 84, no. 4, pp 710-714, 2010.

[23] Mohammad Syahir Bin Ishak, Rahmatul Hidayah Salimin, Ismail Musirin, Zulkiffli Abdul Hamid, "Development of PV array configuration under different partial shading condition" International Journal of Power Electronics and Drive System (IJPEDS), Vol. 10, No. 3, pp. 1263-1269, Sep 2019.

[24] M. Z. Shams El-Dein, Mehrdad Kazerani, M. M. A. Salama, "Optimal Photovoltaic Array Reconfiguration to Reduce Partial Shading Losses,” IEEE Transactions on Sustainable Energy, vol. 4, no. 1, pp. 145-153, Jan 2013.

[25] G. Sai Krishna, Tukaram Moger, "Reconfiguration strategies for reducing partial shading effects in photovoltaic arrays: State of the art,” Solar Energy, Vol. 182, pp. 429-452, Apr 2019. 


\section{BIOGRAPHIES OF AUTHORS}

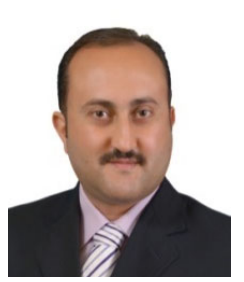

Anas Lateef Mahmood received his B.Sc. in Electronic and Communications Engineering from Al-Nahrain University in 1999. He received his M.Sc. and Ph.D. in Electronic and Communications Engineering / Electronic Circuits and Systems from Al-Nahrain University College of engineering in 2002, and 2007 respectively. He is currently the head of Electronic and Communications Department. His research interest includes power electronics and renewable energy.

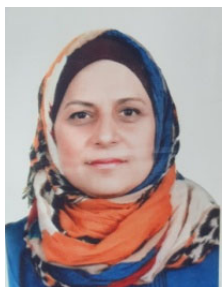

Amina Mahmoud Shakir received the B.Sc. degree in Electrical Engineering from the University of Technology/Baghdad, Iraq in 1990, her M.Sc. in power and machine engineering from the University of Technology/Baghdad, Iraq in 1998, her Ph.D. in power system and machine from Baghdad university in 2007, she is now a lecturer at Al Nahrain University / Electronic and communications Engineering Department. Her interest researches include photovoltaic modeling and control, energy conversion from renewable sources and power electronics. (aminaalkafajiam@gmail.com)

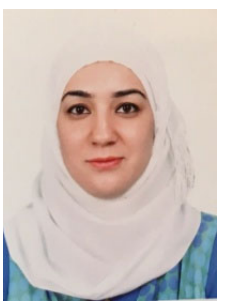

Bahaa Abdulkhaliq Numan is assistant lecturer in college of engineering, electronic and communications department, Al-Nahrain University, Iraq. She got her BSc. degree in electronic engineering from Diyala university, Iraq 2005, MSc. degree in electronic and communications engineering from Al-Nahrain University, Iraq, 2016. Her main interest in the electronic and communications field, power electronic and renewable energy. 